Additional Perspectives articles for Influenza: The Cutting Edge book collection are available at http://perspectivesinmedicine.cshlp.org/cgi/collection/influenza_the_cutting_edge.

\title{
Induction and Evasion of Type-I Interferon Responses during Influenza A Virus Infection
}

\author{
Raquel Muñoz-Moreno, ${ }^{1,2,5}$ Carles Martínez-Romero, ${ }^{1,2,5}$ and Adolfo García-Sastre ${ }^{1,2,3,4}$ \\ ${ }^{1}$ Department of Microbiology, ${ }^{2}$ Global Health and Emerging Pathogens Institute, ${ }^{3}$ Department of Medicine, \\ Division of Infectious Diseases, ${ }^{4}$ The Tisch Cancer Institute, Icahn School of Medicine at Mount Sinai, \\ New York, New York 10029, USA \\ Correspondence: adolfo.garcia-sastre@mssm.edu
}

Influenza A viruses (IAVs) are contagious pathogens and one of the leading causes of respiratory tract infections in both humans and animals worldwide. Upon infection, the innate immune system provides the first line of defense to neutralize or limit the replication of invading pathogens, creating a fast and broad response that brings the cells into an alerted state through the secretion of cytokines and the induction of the interferon (IFN) pathway. At the same time, IAVs have developed a plethora of immune evasion mechanisms in order to avoid or circumvent the host antiviral response, promoting viral replication. Herein, we will review and summarize already known and recently described innate immune mechanisms that host cells use to fight IAV viral infections as well as the main strategies developed by IAVs to overcome such powerful defenses during this fascinating virus-host interplay.

\begin{abstract}
mong the respiratory pathogens that cause Aseasonal epidemics in humans worldwide, influenza viruses are particularly relevant because of their associated burden of disease. In addition, their ability to circulate in several mammalian and avian species provides an optimal scenario for zoonotic transmissions, which have resulted in severe pandemic outbreaks as a result of the introduction of novel influenza virus subtypes in the human population (Horimoto and Kawaoka 2005). The most devastating influenza pandemic ever recorded, the "Spanish Flu," in 1918-1919 decimated 3\% of the world population (Taubenberger et al. 2019). Al-
\end{abstract}

though seasonal epidemics have significantly lower mortality rates, annual cases of severe illness oscillate between 3 and 5 million globally, with 300,000-650,000 deaths (WHO 2018).

Influenza viruses, as well as any other viral pathogen, must overcome the host innate immune response, which is rapidly mounted upon infection by recognizing conserved motifs in the virus. This ignites multiple downstream pathways of cytokine and interferon (IFN) activation to promote antiviral and pro-inflammatory responses, thus restricting early stages of infection before activation of adaptive immunity. In this review, we summarize the mecha-

${ }^{5}$ These authors contributed equally to this work.

Editors: Gabriele Neumann and Yoshihiro Kawaoka

Additional Perspectives on Influenza: The Cutting Edge available at www.perspectivesinmedicine.org

Copyright (C) 2020 Cold Spring Harbor Laboratory Press; all rights reserved

Advanced Online Article. Cite this article as Cold Spring Harb Perspect Med doi: 10.1101/cshperspect.a038414 
R. Muñoz-Moreno et al.

nisms used by the host innate immune response against influenza virus infection, and how the virus has evolved to counteract this first line of defense to successfully infect the host cell, with a special remark on recent advances in our knowledge about virus-host interactions. This review does not pretend to be an exhaustive compendium of the interplay between innate immunity and influenza A virus (IAV) replication, but rather it emphasizes some of the aspects of this interplay as examples of the complexity of the host-virus interactions taking place during IAV infection.

\section{INNATE IMMUNE RESPONSE AND ITS ANTIVIRAL ACTION TO INFLUENZA INFECTION}

Influenza viruses belong to the Orthomyxoviridae family, with a segmented, negative-sense, single-stranded RNA genome. They are classified into four genera (A, B, C, and D) (Shaw and Palese 2013). Influenza $A$ and $B$ viruses are responsible for all seasonal epidemics, whereas influenza $C$ and $D$ viruses are associated with mild disease and are restricted to specific hosts (Wagaman et al. 1989; Ferguson et al. 2016). The influenza A virus (IAV) genome consists of eight single-stranded segments, encapsidated as individual ribonucleotide complexes (RNPs). All segments encode for different proteins with specific roles during viral infection and replication. Among them, the viral hemagglutinin (HA) protein plays a key role in targeting airway and alveolar epithelial cells, mediating host cell recognition and viral entry (Shinya et al.
2006; van Riel et al. 2010). HA binds to sialic acid moieties on carbohydrate side chains of cell-surface glycoproteins and glycolipids (Gambaryan et al. 1997). This interaction induces internalization of the virion via endocytosis (Lakadamyali et al. 2004), and low $\mathrm{pH}$ conditions within the endosome trigger membrane fusion and subsequent release of the viral contents into the cytoplasm (Fontana et al. 2012). Although in humans, and in most mammalian species, influenza virus strains target the respiratory epithelium, in birds, most avian influenza viruses replicate predominantly in intestinal epithelia.

\section{ACTIVATION OF THE INNATE IMMUNE RESPONSE}

\section{Toll-Like Receptors and RIG-I-Like Receptors}

The innate immune response starts when infected cells detect the presence of IAV RNA (Fig. 1). This rapid and nonspecific response is the first line of defense against viral pathogens and it is initially sensed through the recognition of pathogen-associated molecular patterns (PAMPs) via three different types of pattern recognition receptors (PRRs): Toll-like receptors (TLRs), the retinoid acid-inducible gene I (RIG-I), and the NOD-like receptor family member NOD-, LRR-, and pyrin domain-containing 3 (NLRP3) (Garcia-Sastre 2011; Pang and Iwasaki 2012; Iwasaki and Pillai 2014; Kuriakose and Kanneganti 2017). This leads to the innate immune signaling pathway activation, inducing cytokine production as well as the induction of different antiviral molecules (Ouyang et al. 2014; Cao

Figure 1. Schematic diagram of the innate immune response signaling pathway and evasion strategies upon influenza A virus infection. Upon viral replication, $5^{\prime}$-triphosphate single-stranded RNA (ssRNA) and doublestranded RNA (dsRNA) products are recognized by host pathogen recognition receptors (PRRs), which include RIG-I. This leads to a conformational change in RIG-I and causes exposure of its CARD domains that are ubiquitinated by TRIM25. Then, RIG-I associates with MAVS at the mitochondrial membrane, starting a downstream signaling cascade that leads to IRF3, IRF7, and NF- $\kappa B$ transcription factor activation and expression of type-I IFN. Secreted IFN- $\alpha / \beta$ produced by influenza A virus (IAV)-infected cells bind to IFNAR receptors in the cell surface, leading to JAK1/TYK2 phosphorylation and followed by binding and phosphorylation of STAT1 and STAT2 that will form a complex with IRF9. This ISGF-3 complex will function as a transcription factor to activate and transcribe hundreds of genes, among them ISGs, with important roles in mediating the host antiviral response. Red boxes indicate specific sites at which IAV proteins interfere or block the host innate immune response. These mechanisms of evasion are more extensively explained in the text. 
Interferon Responses during Influenza A Virus Infections

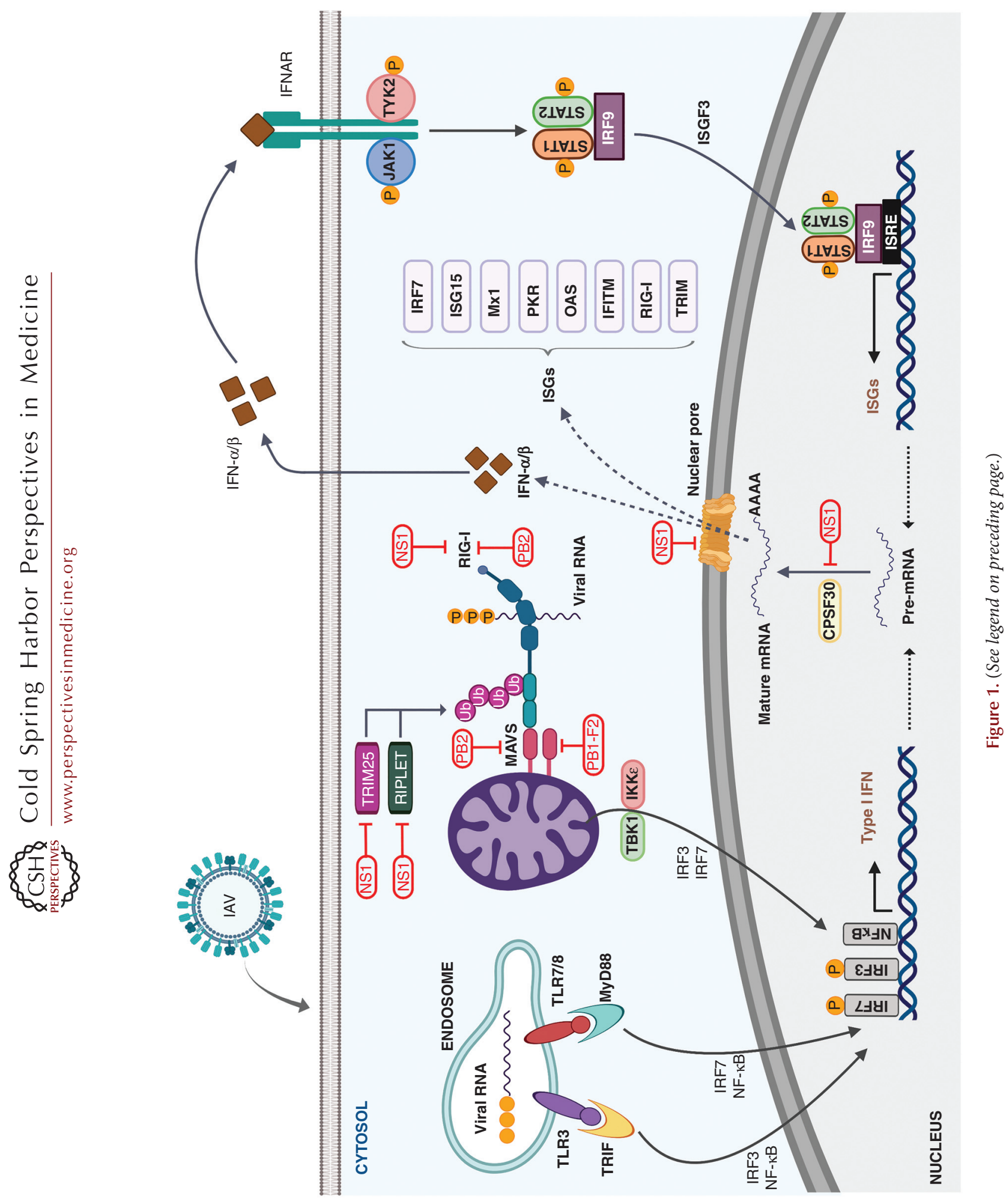


2016). PRRs discriminate self- from non-selfmolecules in infected cells at the endosomal and cytoplasmic compartments thanks to unique viral features that are not found in cellular RNAs, such as the presence of a $5^{\prime}$-triphosphate group or regions of double-stranded RNA (dsRNA) (Hornung et al. 2006; Baum et al. 2010; Rehwinkel et al. 2010).

TLRs are transmembrane proteins that sense viral nucleic acids outside the cell membrane or internally at endosomes and lysosomes through their extracellular domain (Takeshita et al. 2006; Kawai and Akira 2011). TLR3 and TLR7/8 are particularly important for IAV infection, because they can recognize and bind to singlestranded RNA (ssRNA) and dsRNA, respectively (Lund et al. 2004; Blasius and Beutler 2010). Binding of TLRs to RNA occurs through the Toll/IL-1 Receptor (TIR) domains located in the TLR cytoplasmic tails and results in recruitment of adapter molecules: TRIF in the case of TLR3 and Myd88 in the case of TLR7/8 (Kawai and Akira 2011).

IAV intracellular ssRNA and associated transcriptional products are recognized by the RIG-I-like receptors (RLRs) RIG-I, MDA5, and LGP2, which can distinguish between viral and self-cellular RNAs in the cytoplasm of most cell types (Loo and Gale 2011). RLRs contain a central RNA helicase domain, as well as a carboxyterminal repressor domain (RD), necessary for RNA binding. In addition, both RIG-I and MDA5 have tandem amino-terminal caspase activation and recruitment domains (CARDs), which mediate the antiviral transduction signal downstream the RNA recognition but are absent in LGP2 (Takahasi et al. 2009; Bruns and Horvath 2015). RIG-I and MDA5 structurally recognize different RNA species. Although RIG-I recognizes di- and triphosphate groups located at the end of dsRNA (Hornung et al. 2006; Goubau et al. 2014), MDA5 recognizes and binds to long dsRNAs that are potentially IAV replicative intermediates as well as web-like RNA aggregates with no end specificity (Kato et al. 2006; Pichlmair et al. 2006). Despite being structurally related to RIG-I and MDA-5, the specific role of LGP2 is still not clear. However, it is believed that this protein may act as a cofactor, thus mak- ing the viral RNA more accessible to MDA-5 (Venkataraman et al. 2007).

Among all the different RLRs described to date, RIG-I is the best characterized and it is considered to be the main viral RNA sensor that gets activated upon IAV infection, ultimately leading to IFN induction (Kato et al. 2006). Upon PAMP recognition, RIG-I RD binds to RNA 5' triphosphate leading to RIG-I dimerization and activation. Further recognition of dsRNA stimulates ATP hydrolysis and induces RIG-I translocation in the RNA molecule (Myong et al. 2009). This results in a conformational change that leads to CARD domain exposure and ubiquitination by E3 ligases such as TRIM25 (Gack et al. 2007) and RIPLET (Oshiumi et al. 2010). Upon ubiquitination, RIG-I interacts with the mitochondrial antiviral-signaling (MAVS) protein, activating the interferon regulatory factor 3 (IRF-3), IRF7 and the nuclear factor kappa-light-chain-enhancer $(\mathrm{NF}-\kappa \mathrm{B})$. This leads to the expression of a variety of cytokines, such as IFN- $\alpha$ and IFN- $\beta$. Moreover, $N F-\kappa B$ induces the activation of the NLRP3 inflammasome and mediates caspase- 1 activation, subsequently releasing cytokines IL-18 and IL$1 \beta$, which play an important role in the proinflammatory response upon IAV infection (Kuriakose and Kanneganti 2017).

\section{IFN ACTIVATION}

Activation of IRF3, IRF7, and NF- $\mathrm{BB}$ drives the expression of pro-inflammatory cytokines, including TNF, IL6, IL1 $\beta$, and IFN (Hiscott et al. 2006). The innate immune response against IAV infection heavily relies on activating type-I IFN (IFN- $\alpha$ and IFN- $\beta$ ) and type-III IFN (IFN- $\lambda$ ), mounting a response in infected cells in an autocrine manner, but also in noninfected cells through paracrine signaling. IFN- $\alpha / \beta$ and IFN$\lambda$ interact with their respective receptors IFNAR and IFNLR, respectively, inducing the Janus kinase-signal transducer and activator of transcription (JAK-STAT) signaling pathway (Aaronson and Horvath 2002). Downstream phosphorylation of STAT1 and STAT2 leads to the formation of the IFN-stimulated gene factor 3 (ISGF3) complex with the association to IRF9. Upon translo- 
Interferon Responses during Influenza A Virus Infections

cation into the nucleus, ISGF3 drives the transcription of several IFN-stimulated genes (ISGs) by interacting with the IFN-stimulated response element (ISRE) located in the promoter region (Platanias 2005; Schneider et al. 2014). Although both type-I and type-III IFNs were canonically considered to have overlapping functions, recent studies have revealed spatiotemporal differences between IFN- $\alpha / \beta$ and IFN- $\lambda$ (Levy et al. 2011; Hemann et al. 2017). Although both are rapidly induced upon infection, type-I IFNs are promptly modulated to basal levels shortly after, whereas expression of IFN- $\lambda$ is sustained for a longer period of time, localized in specific tissue compartments. Importantly, IFNAR is ubiquitously expressed, whereas IFNLR expression is mainly restricted to epithelial cells. This difference in expression translates into fundamentally different responses upon viral infection. Both IFN- $\alpha / \beta$ and IFN- $\lambda$ have antiviral activity in respiratory epithelial cells. However, IFN- $\lambda$ treatment against IAV has minimal inflammatory side effects in the lungs, contrary to what has been described for IFN- $\alpha / \beta$ (Davidson et al. 2016; Galani et al. 2017).

\section{cGAS/STING}

RIG-I and MDA5 can sense viral RNA to stimulate the signaling via MAVS and downstream to the TANK-binding kinase 1/IRF3 (TBK1-IRF3) pathway. Interestingly, an alternative mechanism that leads to IFN production in a RLR-MAVSindependent manner has been recently described-that is, through stimulator of interferon genes (STING) activation, leading to TBK1-IRF3 and IFN induction (Holm et al. 2016). STING is known to participate in the control of DNA viruses and bacteria, leading to type-I IFN induction upon activation by cyclic GMP-AMP (cGAMP). This molecule is produced after stimulation of the cGAMP synthase (cGAS) in response to cytoplasmic DNA. Moreover, a recent study identified a STING-dependent, cGAS-independent pathway of IFN induction that is triggered by membrane fusion during enveloped virus entry (Holm et al. 2016). This pathway is impaired by the IAV HA2 fusion peptide directly binding to STING, thus preventing STING dimerization and TBK1 activation (Holm et al. 2016).

\section{ISG15}

Among all the ISG that are induced upon type-I IFN stimulation, interferon-stimulated gene 15 (ISG15) is one of the most rapidly up-regulated upon viral infection (Korant et al. 1984; Der et al. 1998). ISG15 is composed of two domains connected through a proline-containing linker that are structurally similar to ubiquitin (Narasimhan et al. 2005). This protein can be released from cells as an extracellular cytokine or proteolytically processed at the carboxy-terminal domain and further covalently conjugated into proteins through its lysine residues (D'Cunha et al. 1996). ISGylation of the target protein occurs through sequential enzymatic reactions similar to ubiquitin conjugation, involving E1 activating, E2 conjugating, and E3 ligase enzymes (Kim et al. 2004; Zhao et al. 2004; Krug et al. 2005; Dastur et al. 2006; Oudshoorn et al. 2012). Through the years, numerous proteins have been identified as targets of ISG15 (Giannakopoulos et al. 2005) even though the consequences of host protein ISGylation still remain poorly understood. ISG15 was first described as a molecule with antiviral activity, because ISG15-deficient mice become more susceptible to viral infection and show increased morbidity and mortality rates for both IAVs and influenza $B$ viruses (IBVs) (Lenschow et al. 2007). Interestingly, ISG15 has been found to play different roles during IAV or IBV infection based on its ability to bind to NS1. For example, IBV NS1 is able to bind ISG15, inhibiting its interaction with its E1 enzyme and preventing the formation of ISG15 conjugates (Yuan and Krug 2001). On the other hand, ISGylation of NS1 of certain IAV strains by ISG15 conjugation impedes its interaction with importin- $\alpha$, restricting nuclear import in detriment to viral replication (Zhao et al. 2010). In any case, although some NS1 of IBV do not bind directly to ISG15, the virus still can inhibit both the IFN response and ISG induction-including ISG15-during infection (Yuan and Krug 2001; Sridharan et al. 2010). This suggests that ISG15 has exerted a different evolutionary pressure of IBV or that IAVs have been able to adapt to such evolutionary pressure through a different mechanism. In any case, the 
antiviral effects of ISG15 in humans are unclear, as ISG15 in humans acts as a negative regulator of IFN signaling by stabilizing its deconjugating enzyme USP18, which in its turn inhibits IFNAR activation (Zhang et al. 2015; Honke et al. 2016).

\section{Mx1}

One of the first ISG that was described to specifically inhibit IAV replication was the Myxovirus resistance gene (Mx1) (Lindenmann 1962). Studies involving the mouse Mx1 locus revealed that the majority of conventional laboratory strains have large deletions or mutations that block proper expression of the Mxl protein (Staeheli et al. 1986, 1988; Haller et al. 1987; Jin et al. 1998). Different Mx1 gene orthologs were described in different classes of vertebrates, including birds, reptiles, fish, and mammals, with different degrees of involvement with the antiviral response against IAV (Bazzigher et al. 1993; Robertsen 2006). Identification of the human Mx genes provided further insights in the evolution of Mx1 and its role in the innate immune response (Aebi et al. 1989). Being a dynamin-like GTPase protein, Mxl can inhibit the replication of many viruses, including IAV (Haller et al. 2015). More details are needed to fully understand how this is accomplished, yet it is known that Mxl interacts with the ribonucleoprotein complex of IAV and of other viruses, interfering with proper viral assembly and eventually blocking replication (Zimmermann et al. 2011; Verhelst et al. 2012). Interestingly, it has been shown that the sequence of NP, the most abundant component of the viral ribonucleoprotein complex, has been selected in human IAV to reduce the strength of binding, which has diminished the human Mx1-mediated antiviral effect (Zimmermann et al. 2011; Manz et al. 2013).

\section{PKR}

The protein kinase RNA-activated (PKR) is a serine/threonine protein kinase constitutively expressed at basal levels in mammalian cells and up-regulated by type-I and type-III IFNs
(Meurs et al. 1990; Ank et al. 2006). PKR is a potent antiviral factor that becomes activated upon dsRNA binding during viral infection (Galabru and Hovanessian 1987). The bestcharacterized PKR cellular substrate is the $\alpha$ subunit of eukaryotic initiation factor eIF2 $(\mathrm{eIF} 2 \alpha)$. Upon viral infection, activated PKR phosphorylates eIF2 $\alpha$, causing translational shutdown of both viral and cellular genes ( $\mathrm{Su}$ et al. 2006). Levels of PKR are also regulated at a post-transcriptional level. At high protein levels, activated PKR inhibits global translation initiation in order to autoregulate the expression of its own mRNA levels (Thomis and Samuel 1992). In this way, PKR can tailor the IFN response by repressing ISG translation in infected cells with IFN-activated PKR while elevating surveillance in uninfected cells in which PKR remains inactive even though its total protein levels are increased by IFN. The importance of $\mathrm{PKR}$ in the antiviral response is underscored by the plethora of viral PKR antagonists found in every virus family (Domingo-Gil et al. 2011). For IAV, the NS1 protein is known to directly bind to PKR, preventing its activation (Bergmann et al. 2000).

\section{OASL}

The ISG family of $2-5^{\prime}$ oligoadenylate synthetases (OASs) promote degradation of viral dsRNA through activation of RNase L (Kristiansen et al. 2011). Later studies unveiled additional antiviral mechanisms independent of RNaseL activity, including the inhibition of IAV replication by the human oligoadenylate synthetaselike (OASL) protein (Zhu et al. 2015). OASL is related to the OAS proteins because it contains the amino-terminal OAS-like domain but cannot induce RNaseL recruitment. Instead, OASL contributes to the antiviral activity by enhancing RIG-I activation (Zhu et al. 2014). In the absence of viral RNA, RIG-I remains inactivated in a folded conformation (O'Neill and Bowie 2011). When RNA is recognized by the carboxy-terminal domain, the amino-terminal caspase activation and recruitment (CARD) domains bind the K63-linked polyubiquitin complexes ( $\mathrm{pUb}$ ) via the E3 ubiquitin ligase 
Interferon Responses during Influenza A Virus Infections

TRIM25. This leads to a conformational change and activation of RIG-I, which starts the aggregation to MAVS via CARD, eventually leading to the IRF3 signaling cascade (Gack et al. 2009). Recent studies have shown that OASL can mediate RIG-I activation in the presence of viral RNA without TRIM25 (Zhu et al. 2014). This is accomplished by mimicking the action of pUb, thus binding to RIG-I directly without additional ligands. Although more details are needed to fully understand its role in the innate immune response, the interaction of OASL with RIG-I opens a new avenue of future antiviral therapies against viruses that are primarily sensed through this pathway.

\section{IFITM}

Several members of the interferon-induced transmembrane (IFITM) family of proteins are key factors in the inhibition of a wide variety of RNA and DNA viruses, including IAV (Brass et al. 2009; Perreira et al. 2013; Li et al. 2018). IFITM proteins are dynamically distributed in the cell membrane and in different organelles, such as lysosomes and endosomes (Bailey et al. 2014). Their mechanism of action is still not fully understood, yet many studies provide enough evidence to affirm that restriction of the infectious cycle by IFITM happens at early stages of the viral entry, by altering membrane fusion either at the cell membrane and/or during endosomal maturation (Perreira et al. 2013; Desai et al. 2014). So far, IFITM1, IFITM2, and IFITM3 have been described to possess antiviral activity, with different degrees of involvement depending on the virus and the site of viral fusion. In regard to IAV infection, IFITM3 appears to be the major contributor of the three to inhibit viral replication (Brass et al. 2009; Feeley et al. 2011; Huang et al. 2011; Li et al. 2013). Although there are many hypotheses as to how IFITM3 mediates this inhibition, recent studies have postulated that IFITMs recruit other cellular proteins to modulate viral fusion ( $\mathrm{Fu}$ et al. 2017). Moreover, evidence suggests that IAV has already evolved to counteract the antiviral action of IFITMs by inhibiting their expression via p53 activation (Wang et al.
2018). Because of the potency of IFITM3 to restrict viral replication, natural variations of the IFITM genes within the human population can modulate the response and possibly contribute to higher sensitivity to infections (Zhao et al. 2019). A particular IFITM3 single-nucleotide polymorphism (SNP), rs12252, was found to be significantly enriched in hospitalized subjects because of IAV infection (Everitt et al. 2012). This confirms the importance of IFITM3 in the innate immune response and how any alteration can dramatically alter its antiviral action.

\section{TRIMs}

The superfamily of tripartite motif-containing (TRIM) proteins is made up of E3 ubiquitinligating enzymes that mediate the last of the three sequential enzymatic reactions necessary for protein ubiquitination. Ubiquitination is a post-translational modification (PTM) of proteins required for diverse cellular processes such as cell cycle progression, transcriptional regulation, and protein degradation by the proteasome, which ultimately consists on allowing reversible ubiquitin linkage to a substrate to activate or deactivate a specific target function (Morreale and Walden 2016). TRIM proteins are structurally conserved and they contain a conserved RBCC domain, which includes a RING (R) domain, one or two B-boxes (B), and a coiled-coil (CC) domain (Ebner et al. 2017; Esposito et al. 2017). Several TRIM proteins are known to be induced by IFN and some TRIM family members have been reported to limit viral replication acting indirectly as components of the innate immune pathway. Such is the case of TRIM56, which efficiently targets both IAV and IBV and elicits an antiviral function through a nondegradative mechanism (Liu et al. 2016). Upon infection, a portion of TRIM56 relocates from the nucleus to the cytoplasm and its presence leads to a reduction of both viral transcription and cRNA synthesis, suggesting that TRIM56 may target a component of the vRNP or the viral RNA itself. Although the specific mechanism of restriction for TRIM56 is still poorly understood, its antiviral activity does not rely on its conserved 
RBCC domain but on a specific region located on the carboxy-terminal tail. In addition to this, other TRIMs directly target viral proteins for proteasomal degradation. For instance, TRIM22 is significantly up-regulated upon IAV infection or IFN treatment and directly targets viral NP for polyubiquitination and further proteasomal degradation (Di Pietro et al. 2013; Lian and Sun 2017). Similarly, TRIM14 has been found to target NP for polyubiquitination and proteasomal degradation through its PRY-SPRY domain (Wu et al. 2019). Contrary to its role in IFN signaling, TRIM14 does not require IFN production to inhibit IAV replication, because $\mathrm{TBK}^{-/-}$and $\mathrm{IFNAR}^{-/-}$cell lines do not prevent TRIM14-mediated restriction of IAV. Other TRIMs have been recently reported to exert an antiviral role against IAV without requiring any prior IFN induction. Such is the case of TRIM41, which can also target viral NP through its SPRY domain for subsequent polyubiquitinmediated degradation (Patil et al. 2018). Overall, these findings show that TRIM proteins can redundantly target NP in order to orchestrate and mount an efficient antiviral response. However, even though NP is a major target for TRIM proteins, other IAV components have been described to be TRIMs substrates. For instance, TRIM32 is a novel PB1 host interactor that is conserved among many different IAV strains. TRIM32 selects PB1 for polyubiquitination and proteasomal degradation leading to decreased polymerase activity and viral replication (Fu et al. 2015). This process does not require prior IFN induction, thus allowing early target and detection of PB1 that is present in uncoated viral particles.

\section{ESCAPING THE HOST INNATE IMMUNE RESPONSE}

Despite having all the mechanisms ready to counteract external pathogens, the host innate immune response is not always successful in preventing viral infections, including IAV. Selective pressure has pushed the immune system to develop more effective strategies that confer protection. But at the same time, viruses like IAV have adapted to overcome these new host barri- ers, by modulating the innate immune response and thus facilitating their replication. Several IAV proteins have been reported to inhibit different components of the host immunity.

\section{NS1}

The IAV nonstructural protein NS1 is nowadays considered the main antagonist of the host innate immune response during viral replication (Greenspan et al. 1988; García-Sastre et al. 1998; Kochs et al. 2007). It is encoded by the smallest IAV RNA segment in conjunction with NEP, a spliced variant of the NS mRNA (Baez et al. 1980). Several functional domains of NS1 confer a wide range of interaction mechanisms with cellular and viral proteins, in order to benefit IAV replication. The amino terminal end of NS1 contains a RNA-binding domain (RBD) that allows its interaction with dsRNA molecules, blocking the activation of RLR sensors such as PKR and OASL (Liu et al. 1997). This mechanism was initially described to be the main function of NS1 to antagonize the host immune response, yet further analysis revealed several other interactions that contribute to this goal (Klemm et al. 2018). NS1 directly interacts with RIG-I to inhibit IFN induction (Mibayashi et al. 2007; Jureka et al. 2015), as well as with TRIM25 and RIPLET to block RIG-I activation (Gack et al. 2009; Rajsbaum et al. 2012). Moreover, NS1 also interacts with PKR, thus preventing IFN activation (Li et al. 2006a; Min et al. 2007). The RBD domain of NS1 contains a nuclear localization signal (NLS) and a selection of viral strains also contain an additional NLS in the carboxy-terminal region (Melén et al. 2007). The NS1 also contains nuclear export signals (NESs) and nucleolar localization domains (Hale et al. 2008). This contributes to the dynamic and diverse localization of NS1 during viral replication both in the nucleus and in the cytoplasm. Because of this, NS1 can also interact with other cellular components, both in the cytoplasm and in the nucleus. NS1 interacts with the $30-\mathrm{kDa}$ subunit of the cleavage and polyadenylation specificity factor (CPSF30) to inhibit cellular mRNA processing and thus inhibit the host antiviral activity (Nemeroff et al. 
Interferon Responses during Influenza A Virus Infections

1998; Noah et al. 2003). This inhibitory activity also promotes host transcriptional antitermination and chromatin remodeling in infected cells (Twu et al. 2006; Bauer et al. 2018). NS1 also targets the inhibitor of kappa B kinase (IKK), eventually inhibiting the nuclear factor kappalight-chain-enhancer of activated B cells $(\mathrm{NK}-\kappa \mathrm{B})$ pathway and therefore preventing the expression of several antiviral genes (Gao et al. 2012). Interestingly, specific IAV strains contain a histone-like sequence in the NS1 protein that suppresses the host antiviral response by binding to the RNA polymerase-associated factor 1 complex (PAF1C) (Marazzi et al. 2012). Other NS1 activities that contribute to overcome the antiviral response include the inhibition of nuclear export of host mRNA (Zhang et al. 2019), as well as activation of transcriptional repressors, such as the CCAAT/Enhancer Binding Protein beta (C/EBP $\beta)$, which NS1 recruits to act as a repressor element in the RIG-I promoter (Kumari et al. 2020). Moreover, almost every NS1 protein contains a carboxy-terminal binding motif that targets class $1 \mathrm{PDZ}$ domains (Obenauer et al. 2006), which are mediating protein-protein interactions in a wide variety of cellular pathways (Fanning and Anderson 1999). This PDZ domain binding motif (PBM) in the NS1 protein has been suggested to be a virulence determinant, because carboxy-terminal truncations or extensions result in attenuation of the virus (Li et al. 2006b; Soubies et al. 2010).

The mechanisms by which IAV NS1 modulates the cellular machinery to promote viral replication include such a wide range of pathways that highlights its relevance as a multifunctional virulence factor. Because of the intrinsic mutational rate of IAV during replication and its ability to infect different hosts, NS1 is in constant evolutionary pressure. Our recent research efforts have analyzed the NS1 evolutionary landscape and host tropism using a barcoded NS1 library of recombinant NS1 IAV, providing new insights on the plasticity of the protein and its ability to adapt to different hosts (MuñozMoreno et al. 2019). Following studies may describe new details about NS1 evolution, discovering new interactors to advance our under- standing of how IAV counteracts the host innate immunity. In any case, NS1 mutated recombinant IAV represent potential novel live attenuated vaccines against human IAV (Wang et al. 2019a), and they are currently being used in the field as vaccines in pigs against swine influenza because of their ability to induce broad protective responses against multiple swine influenza virus strains (Genzow et al. 2018).

\section{Viral Polymerase}

The IAV polymerase also plays a role in regulating the host antiviral response. Early after viral infection, when a reduced number of viral components are still present in infected cells, the viral polymerase complex can inhibit IFN- $\beta$ promoter activity in a RIG-I- and MAVS-dependent manner. This inhibition of the type-I IFN response does not compete with the function of NS1, being more efficiently promoted by the PB2 polymerase subunit (Graef et al. 2010; Iwai et al. 2010). In previous years, the role of the viral polymerase in inhibiting the IFN response had been partially supported through studies using UV-inactivated IAV (Marcus et al. 2005) and through systems biology analysis to elucidate novel viral-host interactors (Shapira et al. 2009). Recent studies in the field have shown that the IAV PA protein also interacts with IRF3 to suppress IFN- $\beta$ production (Yi et al. 2017). The amino-terminal endonuclease activity of PA is required for this interaction, revealing a new strategy by which IAV blocks IFN- $\beta$ signaling. It is also worth mentioning that some IAV proteins-including the viral polymerase-are known virulence and pathogenicity contributors. Therefore, it is not surprising that viruses carrying highly efficient polymerases have increased fitness abilities that can better outcompete the host antiviral response (Grimm et al. 2007).

\section{PA-X}

The polymerase acidic (PA) protein is the canonical product translated from IAV RNA segment 3. However, an alternative open reading frame (ORF) was discovered to produce a highly 
conserved fusion protein among strains, called PA-X (Jagger et al. 2012). Initial studies revealed PA-X to be influencing the host immune response, thus affecting viral replication and pathogenicity (Gao et al. 2015; Hu et al. 2018). However, its action seems to be strain-specific and the reasoning behind it remains elusive. In any case, PA-X is known to cleave host transcripts in the nucleus, degrading them via the host RNase Xrn1 and facilitating the processing of IAV mRNAs (Khaperskyy et al. 2016).

\section{PB1-F2}

Segment 2 of the IAV genome encodes for the RNA polymerase basic protein 1 (PB1), which is a subunit of the viral RNA polymerase complex. There is an alternative ORF within segment 2 of specific IAV strains that produces a second protein, called PB1-F2, originally described as a promoter of cell apoptosis, localized in the mitochondria of immune cells (Chen et al. 2001). Increased levels of reactive oxygen species (ROS) have been associated with the inhibition of the superoxide anion dismutase 1 (SOD1) by PB1F2 (Shin et al. 2015). Further studies revealed a specific point mutation in the PB1-F2 sequence of highly virulent H5N1 IAV strains, which increases its pro-apoptotic properties and thus its viral pathogenicity (Conenello et al. 2007). Moreover, natural killer (NK) cell inhibition and neutrophil recruitment have been associated with the presence of PB1-F2, which also exacerbates pathogenicity (Vidy et al. 2016). Finally, PB1-F2 is also inhibiting the IFN response by modulation of MAVS through the host protein calcium-binding and coiled-coil domain 2 (NDP52) (Varga et al. 2011; Leymarie et al. 2017).

\section{M2}

The influenza virus matrix protein 2 (M2) is a small proton ion channel transmembrane protein encoded in segment 7 through alternative splicing that is important in several steps of IAV replication cycle. During viral entry, the low $\mathrm{pH}$ in endosomes activates the ion channel activity of M2, pumping protons toward the in- terior of the virion and promoting the release of vRNP into the cytoplasm after membrane fusion (Pinto et al. 1992). In addition, the ion channel activity of M2 also regulates the $\mathrm{pH}$ balance between the cytoplasm and the acidic lumen of the trans-Golgi network (TGN), in order to protect HA from $\mathrm{pH}$-induced premature conformational changes (Ciampor et al. 1992; Sakaguchi et al. 1996). To date, how IAV M2 protein can evade the host immune response remains poorly understood. However, recent studies have shown that M2 is able to anchor to mitochondria in both virus-infected and M2-overexpressing cells, accelerating MAVS self-association and aggregate formation, thus promoting a MAVS-mediated antiviral immunity (Wang et al. 2019b). Moreover, M2 can increase levels of $\mathrm{Ca}^{+2}$ into the cytoplasm, ultimately resulting in ROS production and autophagy activation. Such autophagy stimulation leads to MAVS-mediated innate immune signaling inhibition and MAVS aggregates regulation though direct binding of MAVS to ATG5 (Jounai et al. 2007; Zhao et al. 2012) and LC3B (Sun et al. 2016; Cheng et al. 2017). Meanwhile, M2 can also block the last step of the autolysosome formation during autophagy, reducing excessive elimination of MAVS aggregates and ROS (Wang et al. 2019b) and preventing the antiviral consequences of autophagy (Rossman and Lamb 2009; Zhang et al. 2014). In summary, M2 can be defined as a tight regulator of the innate immune response that is able to trigger MAVS signaling activation while preventing excessive activation of RLR signaling and inhibiting antiviral autophagic processes.

\section{FINAL REMARKS}

There is a complex and dynamic interplay between IAVs to efficiently promote virus replication and the host innate immune response to counteract and fight against viral infections. The molecular basis of these virus-host interactions has been extensively investigated over the last two decades, providing further insights into the mechanisms that the host cell uses upon IAV infection to efficiently control the disease outcome. Given the high diversity of IAV and the 
Interferon Responses during Influenza A Virus Infections

relatively conserved nature of the host innate immune response, further research efforts in this field are needed to provide a deeper understanding and to enable the development of more effective antiviral treatments that could be used against multiple IAV strains/subtypes and the prevention of future pandemics.

\section{ACKNOWLEDGMENTS}

Research in the A.G.-S. lab is supported by $\mathrm{Na}-$ tional Institutes of Health (NIH) grants U19AI 118610, U01AI124297, R01AI125524, R01AI12 7658, R01AI127302, R33AI119304, R01AI127 775, U19AI135972, R01CA229818, P01AI097 092, R21AI142337, R01AI141226, R01AI1420 86, U19AI142733, R21AI147201, U01EB029 085, and U01HL146240; National Institute of Allergy and Infectious Diseases (NIAID) contracts HHSN272201800010I, 75N93019C00 051, and 75N93019C00046; Department of Defense (DoD) grants W81XWH-18-1-0488 and W81XWH-19-PRMRP-FPA; Defense Advanced Research Projects Agency (DARPA) grant HR0011-19-2-0020, and by the NIAIDfunded Centers of Excellence for Influenza Research and Surveillance (CEIRS) network, under a contract for a Center of Research in Influenza Pathogenesis (CRIP) (HHSN272201400008C). A.G-S. discloses research funding on the area of veterinarian influenza virus vaccines by Avimex and consulting relationships for the companies Avimex, 7Hills, and Farmak. A.G.-S. is an inventor in patents on IAV vaccines owned by the Icahn School of Medicine at Mount Sinai.

This article has been made freely available online courtesy of TAUNS Laboratories.

\section{REFERENCES}

Aaronson DS, Horvath CM. 2002. A road map for those who don't know JAK-STAT. Science 296: 1653-1655. doi:10 $.1126 /$ science. 1071545

Aebi M, Fäh J, Hurt N, Samuel CE, Thomis D, Bazzigher L, Pavlovic J, Haller O, Staeheli P. 1989. cDNA structures and regulation of two interferon-induced human $\mathrm{Mx}$ proteins. Mol Cell Biol 9: 5062-5072. doi:10.1128/MCB.9.11 .5062

Ank N, West H, Bartholdy C, Eriksson K, Thomsen AR, Paludan SR. 2006. Lambda interferon (IFN- $\lambda$ ), a type
III IFN, is induced by viruses and IFNs and displays potent antiviral activity against select virus infections in vivo. J Virol 80: 4501-4509. doi:10.1128/JVI.80.9.45014509.2006

Baez M, Taussig R, Zazra JJ, Young JF, Palese P, Reisfeld A, Skalka AM. 1980. Complete nucleotide sequence of the influenza $\mathrm{A} / \mathrm{PR} / 8 / 34$ virus NS gene and comparison with the NS genes of the A/Udorn/72 and A/FPV/Rostock/34 strains. Nucleic Acids Res 8: 5845-5858. doi:10.1093/nar/ 8.23.5845

Bailey CC, Zhong G, Huang IC, Farzan M. 2014. IFITMfamily proteins: the cell's first line of antiviral defense. Annu Rev Virol 1: 261-283. doi:10.1146/annurev-virolo gy-031413-085537

Bauer DLV, Tellier M, Martínez-Alonso M, Nojima T, Proudfoot NJ, Murphy S, Fodor E. 2018. Influenza virus mounts a two-pronged attack on host RNA polymerase II transcription. Cell Rep 23: 2119-2129.e3. doi:10.1016/j .celrep.2018.04.047

Baum A, Sachidanandam R, García-Sastre A. 2010. Preference of RIG-I for short viral RNA molecules in infected cells revealed by next-generation sequencing. Proc Natl Acad Sci 107: 16303-16308. doi:10.1073/pnas 1005077107

Bazzigher L, Schwarz A, Staeheli P. 1993. No enhanced influenza virus resistance of murine and avian cells expressing cloned duck Mx protein. Virology 195: 100-112. doi:10.1006/viro.1993.1350

Bergmann M, García-Sastre A, Carnero E, Pehamberger H, Wolff K, Palese P, Muster T. 2000. Influenza virus NS1 protein counteracts $\mathrm{PKR}$-mediated inhibition of replication. J Virol 74: 6203-6206. doi:10.1128/JVI.74.13.62036206.2000

Blasius AL, Beutler B. 2010. Intracellular toll-like receptors. Immunity 32: 305-315. doi:10.1016/j.immuni.2010.03 .012

Brass AL, Huang IC, Benita Y, John SP, Krishnan MN, Feeley EM, Ryan BJ, Weyer JL, van der Weyden L, Fikrig E, et al. 2009. The IFITM proteins mediate cellular resistance to influenza A H1N1 virus, West Nile virus, and dengue virus. Cell 139: 1243-1254. doi:10 .1016/j.cell.2009.12.017

Bruns AM, Horvath CM. 2015. LGP2 synergy with MDA5 in RLR-mediated RNA recognition and antiviral signaling. Cytokine 74: 198-206. doi:10.1016/j.cyto.2015.02 .010

Cao X. 2016. Self-regulation and cross-regulation of patternrecognition receptor signalling in health and disease. Nat Rev Immunol 16: 35-50. doi:10.1038/nri.2015.8

Chen W, Calvo PA, Malide D, Gibbs J, Schubert U, Bacik I, Basta S, O’Neill R, Schickli J, Palese P, et al. 2001. A novel influenza A virus mitochondrial protein that induces cell death. Nat Med 7: 1306-1312. doi:10.1038/ nm1201-1306

Cheng J, Liao Y, Xiao L, Wu R, Zhao S, Chen H, Hou B, Zhang X, Liang C, Xu Y, et al. 2017. Autophagy regulates MAVS signaling activation in a phosphorylation-dependent manner in microglia. Cell Death Differ 24: 276-287. doi:10.1038/cdd.2016.121

Ciampor F, Bayley PM, Nermut MV, Hirst EM, Sugrue RJ, Hay AJ. 1992. Evidence that the amantadine-induced, M2-mediated conversion of influenza A virus hemagglu- 
R. Muñoz-Moreno et al.

tinin to the low $\mathrm{pH}$ conformation occurs in an acidic trans Golgi compartment. Virology 188: 14-24. doi:10.1016/ 0042-6822(92)90730-D

Conenello GM, Zamarin D, Perrone LA, Tumpey T, Palese P. 2007. A single mutation in the PB1-F2 of H5N1 (HK/97) and 1918 influenza A viruses contributes to increased virulence. PLoS Pathog 3: 1414-1421. doi:10.1371/jour nal.ppat.0030141

Dastur A, Beaudenon S, Kelley M, Krug RM, Huibregtse JM. 2006. Herc5, an interferon-induced HECT E3 enzyme, is required for conjugation of ISG15 in human cells. J Biol Chem 281: 4334-4338. doi:10.1074/jbc.M512830200

Davidson S, McCabe TM, Crotta S, Gad HH, Hessel EM, Beinke S, Hartmann R, Wack A. 2016. IFN $\lambda$ is a potent anti-influenza therapeutic without the inflammatory side effects of IFN $\alpha$ treatment. EMBO Mol Med 8: 1099-1112. doi:10.15252/emmm.201606413

D’Cunha J, Ramanujam S, Wagner RJ, Witt PL, Knight E Jr, Borden EC. 1996. In vitro and in vivo secretion of human ISG15, an IFN-induced immunomodulatory cytokine. $J$ Immunol 157: 4100-4108.

Der SD, Zhou A, Williams BR, Silverman RH. 1998. Identification of genes differentially regulated by interferon $\alpha, \beta$, or $\gamma$ using oligonucleotide arrays. Proc Natl Acad Sci 95: 15623-15628. doi:10.1073/pnas.95.26.15623

Desai TM, Marin M, Chin CR, Savidis G, Brass AL, Melikyan GB. 2014. IFITM3 restricts influenza A virus entry by blocking the formation of fusion pores following virusendosome hemifusion. PLoS Pathog 10: e1004048. doi:10 .1371/journal.ppat.1004048

Di Pietro A, Kajaste-Rudnitski A, Oteiza A, Nicora L, Towers GJ, Mechti N, Vicenzi E. 2013. TRIM22 inhibits influenza A virus infection by targeting the viral nucleoprotein for degradation. J Virol 87: 4523-4533. doi:10.1128/JVI .02548-12

Domingo-Gil E, Toribio R, Nájera JL, Esteban M, Ventoso I. 2011. Diversity in viral anti-PKR mechanisms: a remarkable case of evolutionary convergence. PLoS One 6: e16711. doi:10.1371/journal.pone.0016711

Ebner P, Versteeg GA, Ikeda F. 2017. Ubiquitin enzymes in the regulation of immune responses. Crit Rev Biochem Mol Biol 52: 425-460. doi:10.1080/10409238.2017 .1325829

Esposito D, Koliopoulos MG, Rittinger K. 2017. Structural determinants of TRIM protein function. Biochem Soc Trans 45: 183-191. doi:10.1042/BST20160325

Everitt AR, Clare S, Pertel T, John SP, Wash RS, Smith SE, Chin CR, Feeley EM, Sims JS, Adams DJ, et al. 2012 IFITM3 restricts the morbidity and mortality associated with influenza. Nature 484: 519-523. doi:10.1038/na ture10921

Fanning AS, Anderson JM. 1999. PDZ domains: fundamental building blocks in the organization of protein complexes at the plasma membrane. J Clin Invest 103: 767772. doi:10.1172/JCI6509

Feeley EM, Sims JS, John SP, Chin CR, Pertel T, Chen LM, Gaiha GD, Ryan BJ, Donis RO, Elledge SJ, et al. 2011. IFITM3 inhibits influenza A virus infection by preventing cytosolic entry. PLoS Pathog 7: e1002337. doi:10.1371/ journal.ppat.1002337

Ferguson L, Olivier AK, Genova S, Epperson WB, Smith DR, Schneider L, Barton K, McCuan K, Webby RJ, Wan XF.
2016. Pathogenesis of influenza D virus in cattle. J Virol 90: 5636-5642. doi:10.1128/JVI.03122-15

Fontana J, Cardone G, Heymann JB, Winkler DC, Steven AC. 2012. Structural changes in influenza virus at low $\mathrm{pH}$ characterized by cryo-electron tomography. J Virol 86: 2919-2929. doi:10.1128/JVI.06698-11

Fu B, Wang L, Ding H, Schwamborn JC, Li S, Dorf ME. 2015. TRIM32 senses and restricts influenza A virus by ubiquitination of PB1 polymerase. PLoS Pathog 11: e1004960. doi:10.1371/journal.ppat.1004960

Fu B, Wang L, Li S, Dorf ME. 2017. ZMPSTE24 defends against influenza and other pathogenic viruses. J Exp Med 214: 919-929. doi:10.1084/jem.20161270

Gack MU, Shin YC, Joo CH, Urano T, Liang C, Sun L, Takeuchi O, Akira S, Chen Z, Inoue S, et al. 2007. TRIM25 RING-finger E3 ubiquitin ligase is essential for RIG-Imediated antiviral activity. Nature 446: 916-920. doi:10 $.1038 /$ nature 05732

Gack MU, Albrecht RA, Urano T, Inn KS, Huang IC, Carnero E, Farzan M, Inoue S, Jung JU, García-Sastre A. 2009. Influenza A virus NS1 targets the ubiquitin ligase TRIM25 to evade recognition by the host viral RNA sensor RIG-I. Cell Host Microbe 5: 439-449. doi:10.1016/j .chom.2009.04.006

Galabru J, Hovanessian A. 1987. Autophosphorylation of the protein kinase dependent on double-stranded RNA. J Biol Chem 262: 15538-15544.

Galani IE, Triantafyllia V, Eleminiadou EE, Koltsida O, Stavropoulos A, Manioudaki M, Thanos D, Doyle SE, Kotenko SV, Thanopoulou K, et al. 2017. Interferon- $\lambda$ mediates non-redundant front-line antiviral protection against influenza virus infection without compromising host fitness. Immunity 46: 875-890.e6. doi:10.1016/j .immuni.2017.04.025

Gambaryan AS, Tuzikov AB, Piskarev VE, Yamnikova SS, Lvov DK, Robertson JS, Bovin NV, Matrosovich MN. 1997. Specification of receptor-binding phenotypes of influenza virus isolates from different hosts using synthetic sialylglycopolymers: non-egg-adapted human $\mathrm{H} 1$ and $\mathrm{H} 3$ influenza $A$ and influenza $B$ viruses share a common high binding affinity for $6^{\prime}$-sialyl( $N$-acetyllactosamine). Virology 232: 345-350. doi:10.1006/viro.1997.8572

Gao S, Song L, Li J, Zhang Z, Peng H, Jiang W, Wang Q, Kang T, Chen S, Huang W. 2012. Influenza A virus-encoded NS1 virulence factor protein inhibits innate immune response by targeting IKK. Cell Microbiol 14: 1849-1866. doi:10.1111/cmi.12005

Gao H, Sun Y, Hu J, Qi L, Wang J, Xiong X, Wang Y, He Q, Lin Y, Kong W, et al. 2015. The contribution of PA-X to the virulence of pandemic $2009 \mathrm{H} 1 \mathrm{~N} 1$ and highly pathogenic H5N1 avian influenza viruses. Sci Rep 5: 8262. doi:10.1038/srep08262

García-Sastre A. 2011. Induction and evasion of type I interferon responses by influenza viruses. Virus Res 162: 12-18. doi:10.1016/j.virusres.2011.10.017

García-Sastre A, Egorov A, Matassov D, Brandt S, Levy DE, Durbin JE, Palese P, Muster T. 1998. Influenza A virus lacking the NS1 gene replicates in interferon-deficient systems. Virology 252: 324-330. doi:10.1006/viro.1998 .9508

Genzow M, Goodell C, Kaiser TJ, Johnson W, Eichmeyer M. 2018. Live attenuated influenza virus vaccine reduces 
virus shedding of newborn piglets in the presence of maternal antibody. Influenza Other Respir Viruses 12: $353-$ 359. doi:10.1111/irv.12531

Giannakopoulos NV, Luo JK, Papov V, Zou W, Lenschow DJ, Jacobs BS, Borden EC, Li J, Virgin HW, Zhang DE. 2005. Proteomic identification of proteins conjugated to ISG15 in mouse and human cells. Biochem Biophys Res Commun 336: 496-506. doi:10.1016/j.bbrc.2005.08.132

Goubau D, Schlee M, Deddouche S, Pruijssers AJ, Zillinger T, Goldeck M, Schuberth C, Van der Veen AG, Fujimura T, Rehwinkel J, et al. 2014. Antiviral immunity via RIG-Imediated recognition of RNA bearing $5^{\prime}$-diphosphates. Nature 514: 372-375. doi:10.1038/nature13590

Graef KM, Vreede FT, Lau YF, McCall AW, Carr SM, Subbarao K, Fodor E. 2010. The PB2 subunit of the influenza virus RNA polymerase affects virulence by interacting with the mitochondrial antiviral signaling protein and inhibiting expression of beta interferon. J Virol 84: 8433-8445. doi:10.1128/JVI.00879-10

Greenspan D, Palese P, Krystal M. 1988. Two nuclear location signals in the influenza virus NS1 nonstructural protein. J Virol 62: 3020-3026. doi:10.1128/JVI.62.8 .3020-3026.1988

Grimm D, Staeheli P, Hufbauer M, Koerner I, MartínezSobrido L, Solorzano A, García-Sastre A, Haller O, Kochs G. 2007. Replication fitness determines high virulence of influenza A virus in mice carrying functional $M x 1$ resistance gene. Proc Natl Acad Sci 104: 6806-6811. doi:10 $.1073 /$ pnas.0701849104

Hale BG, Randall RE, Ortín J, Jackson D. 2008. The multifunctional NS1 protein of influenza A viruses. J Gen Virol 89: 2359-2376. doi:10.1099/vir.0.2008/004606-0

Haller O, Acklin M, Staeheli P. 1987. Influenza virus resistance of wild mice: wild-type and mutant $\mathrm{Mx}$ alleles occur at comparable frequencies. J Interferon Res 7: 647-656. doi:10.1089/jir.1987.7.647

Haller O, Staeheli P, Schwemmle M, Kochs G. 2015. Mx GTPases: dynamin-like antiviral machines of innate immunity. Trends Microbiol 23: 154-163. doi:10.1016/j.tim .2014 .12 .003

Hemann EA, Gale M Jr, Savan R. 2017. Interferon lambda genetics and biology in regulation of viral control. Front Immunol 8: 1707. doi:10.3389/fimmu.2017.01707

Hiscott J, Lin R, Nakhaei P, Paz S. 2006. MasterCARD: a priceless link to innate immunity. Trends Mol Med 12: 53-56. doi:10.1016/j.molmed.2005.12.003

Holm CK, Rahbek SH, Gad HH, Bak RO, Jakobsen MR, Jiang Z, Hansen AL, Jensen SK, Sun C, Thomsen MK, et al. 2016. Influenza A virus targets a cGAS-independent STING pathway that controls enveloped RNA viruses. Nat Commun 7: 10680. doi:10.1038/ncomms10680

Honke N, Shaabani N, Zhang DE, Hardt C, Lang KS. 2016. Multiple functions of USP18. Cell Death Dis 7: e2444. doi:10.1038/cddis.2016.326

Horimoto T, Kawaoka Y. 2005. Influenza: lessons from past pandemics, warnings from current incidents. Nat Rev Microbiol 3: 591-600. doi:10.1038/nrmicro1208

Hornung V, Ellegast J, Kim S, Brzozka K, Jung A, Kato H, Poeck H, Akira S, Conzelmann KK, Schlee M, et al. 2006. 5'-Triphosphate RNA is the ligand for RIG-I. Science 314: 994-997. doi:10.1126/science.1132505
Hu J, Ma C, Liu X. 2018. PA-X: a key regulator of influenza A virus pathogenicity and host immune responses. Med Microbiol Immunol 207: 255-269. doi:10.1007/s00430018-0548-z

Huang IC, Bailey CC, Weyer JL, Radoshitzky SR, Becker MM, Chiang JJ, Brass AL, Ahmed AA, Chi X, Dong L, et al. 2011. Distinct patterns of IFITM-mediated restriction of filoviruses, SARS coronavirus, and influenza A virus. PLoS Pathog 7: e1001258. doi:10.1371/journal .ppat.1001258

Iwai A, Shiozaki T, Kawai T, Akira S, Kawaoka Y, Takada A, Kida H, Miyazaki T. 2010. Influenza A virus polymerase inhibits type I interferon induction by binding to interferon $\beta$ promoter stimulator 1. J Biol Chem 285: 3206432074. doi:10.1074/jbc.M110.112458

Iwasaki A, Pillai PS. 2014. Innate immunity to influenza virus infection. Nat Rev Immunol 14: 315-328. doi:10 $.1038 / \mathrm{nri3665}$

Jagger BW, Wise HM, Kash JC, Walters KA, Wills NM, Xiao YL, Dunfee RL, Schwartzman LM, Ozinsky A, Bell GL, et al. 2012. An overlapping protein-coding region in influenza A virus segment 3 modulates the host response Science 337: 199-204. doi:10.1126/science.1222213

Jin HK, Yamashita T, Ochiai K, Haller O, Watanabe T. 1998. Characterization and expression of the Mxl gene in wild mouse species. Biochem Genet 36: 311-322. doi:10.1023/ A:1018741312058

Jounai N, Takeshita F, Kobiyama K, Sawano A, Miyawaki A, Xin KQ, Ishii KJ, Kawai T, Akira S, Suzuki K, et al. 2007. The Atg5 Atg12 conjugate associates with innate antiviral immune responses. Proc Natl Acad Sci 104: 14050-14055. doi:10.1073/pnas.0704014104

Jureka AS, Kleinpeter AB, Cornilescu G, Cornilescu CC, Petit CM. 2015. Structural basis for a novel interaction between the NS1 protein derived from the 1918 influenza virus and RIG-I. Structure 23: 2001-2010. doi:10.1016/j .str.2015.08.007

Kato H, Takeuchi O, Sato S, Yoneyama M, Yamamoto M, Matsui K, Uematsu S, Jung A, Kawai T, Ishii KJ, et al. 2006. Differential roles of MDA5 and RIG-I helicases in the recognition of RNA viruses. Nature 441: 101-105. doi:10.1038/nature04734

Kawai T, Akira S. 2011. Toll-like receptors and their crosstalk with other innate receptors in infection and immunity. Immunity 34: 637-650. doi:10.1016/j.immuni.2011.05 .006

Khaperskyy DA, Schmaling S, Larkins-Ford J, McCormick C, Gaglia MM. 2016. Selective degradation of host RNA polymerase II transcripts by influenza A virus PA-X host shutoff protein. PLoS Pathog 12: e1005427. doi:10.1371/ journal.ppat. 1005427

Kim KI, Giannakopoulos NV, Virgin HW, Zhang DE. 2004. Interferon-inducible ubiquitin $\mathrm{E} 2, \mathrm{Ubc} 8$, is a conjugating enzyme for protein ISGylation. Mol Cell Biol 24: 95929600. doi:10.1128/MCB.24.21.9592-9600.2004

Klemm C, Boergeling Y, Ludwig S, Ehrhardt C. 2018. Immunomodulatory nonstructural proteins of influenza A viruses. Trends Microbiol 26: 624-636. doi:10.1016/j.tim .2017 .12 .006

Kochs G, García-Sastre A, Martínez-Sobrido L. 2007. Multiple anti-interferon actions of the influenza A virus NS1 protein. J Virol 81: 7011-7021. doi:10.1128/JVI.02581-06 
R. Muñoz-Moreno et al.

Korant BD, Blomstrom DC, Jonak GJ, Knight E Jr. 1984 Interferon-induced proteins. Purification and characterization of a 15,000-dalton protein from human and bovine cells induced by interferon. J Biol Chem 259: 1483514839 .

Kristiansen H, Gad HH, Eskildsen-Larsen S, Despres P, Hartmann R. 2011. The oligoadenylate synthetase family: an ancient protein family with multiple antiviral activities. J Interferon Cytokine Res 31: 41-47. doi:10.1089/jir .2010 .0107

Krug RM, Zhao C, Beaudenon S. 2005. Properties of the ISG15 E1 enzyme UbE1L. Methods Enzymol 398: 3240. doi:10.1016/S0076-6879(05)98004-X

Kumari R, Guo Z, Kumar A, Wiens M, Gangappa S, Katz JM, Cox NJ, Lal RB, Sarkar D, Fisher PB, et al. 2020. Influenza virus NS1- C/EBP $\beta$ gene regulatory complex inhibits RIG-I transcription. Antiviral Res 176: 104747. doi:10 .1016/j.antiviral.2020.104747

Kuriakose T, Kanneganti TD. 2017. Regulation and functions of NLRP3 inflammasome during influenza virus infection. Mol Immunol 86: 56-64. doi:10.1016/j .molimm.2017.01.023

Lakadamyali M, Rust MJ, Zhuang X. 2004. Endocytosis of influenza viruses. Microbes Infect 6: 929-936. doi:10 .1016/j.micinf.2004.05.002

Lenschow DJ, Lai C, Frias-Staheli N, Giannakopoulos NV, Lutz A, Wolff T, Osiak A, Levine B, Schmidt RE, GarcíaSastre A, et al. 2007. IFN-stimulated gene 15 functions as a critical antiviral molecule against influenza, herpes, and Sindbis viruses. Proc Natl Acad Sci 104: 1371-1376. doi:10.1073/pnas.0607038104

Levy DE, Marié IJ, Durbin JE. 2011. Induction and function of type I and III interferon in response to viral infection. Curr Opin Virol 1: 476-486. doi:10.1016/j.coviro.2011.11 .001

Leymarie O, Meyer L, Tafforeau L, Lotteau V, Costa BD, Delmas B, Chevalier C, Le Goffic R. 2017. Influenza virus protein PB1-F2 interacts with CALCOCO2 (NDP52) to modulate innate immune response. J Gen Virol 98: 1196 1208. doi:10.1099/jgv.0.000782

Li S, Min JY, Krug RM, Sen GC. 2006a. Binding of the influenza A virus NS1 protein to PKR mediates the inhibition of its activation by either PACT or double-stranded RNA. Virology 349: 13-21. doi:10.1016/j.virol.2006.01 .005

Li Z, Jiang Y, Jiao P, Wang A, Zhao F, Tian G, Wang X, Yu K, $\mathrm{Bu} \mathrm{Z}$, Chen H. 2006b. The NS1 gene contributes to the virulence of $\mathrm{H} 5 \mathrm{~N} 1$ avian influenza viruses. $J$ Virol 80: 11115-11123. doi:10.1128/JVI.00993-06

Li K, Markosyan RM, Zheng YM, Golfetto O, Bungart B, Li M, Ding S, He Y, Liang C, Lee JC, et al. 2013. IFITM proteins restrict viral membrane hemifusion. PLoS Pathog 9: e1003124. doi:10.1371/journal.ppat.1003124

Li C, Du S, Tian M, Wang Y, Bai J, Tan P, Liu W, Yin R, Wang M, Jiang Y, et al. 2018. The host restriction factor interferon-inducible transmembrane protein 3 inhibits vaccinia virus infection. Front Immunol 9: 228. doi:10 .3389/fimmu.2018.00228

Lian Q, Sun B. 2017. Interferons command Trim22 to fight against viruses. Cell Mol Immunol 14: 794-796. doi:10 $.1038 / \mathrm{cmi} .2017 .76$
Lindenmann J. 1962. Resistance of mice to mouse-adapted influenza A virus. Virology 16: 203-204. doi:10.1016/ 0042-6822(62)90297-0

Liu J, Lynch PA, Chien CY, Montelione GT, Krug RM, Berman HM. 1997. Crystal structure of the unique RNAbinding domain of the influenza virus NS1 protein. Nat Struct Biol 4: 896-899. doi:10.1038/nsb1197-896

Liu B, Li NL, Shen Y, Bao X, Fabrizio T, Elbahesh H, Webby RJ, Li K. 2016. The C-terminal tail of TRIM56 dictates antiviral restriction of influenza $\mathrm{A}$ and $\mathrm{B}$ viruses by impeding viral RNA synthesis. J Virol 90: 4369-4382. doi:10 $.1128 /$ JVI.03172-15

Loo YM, Gale M Jr. 2011. Immune signaling by RIG-I-like receptors. Immunity 34: 680-692. doi:10.1016/j.immuni .2011.05.003

Lund JM, Alexopoulou L, Sato A, Karow M, Adams NC, Gale NW, Iwasaki A, Flavell RA. 2004. Recognition of single-stranded RNA viruses by Toll-like receptor 7 . Proc Natl Acad Sci 101: 5598-5603. doi:10.1073/pnas .0400937101

Manz B, Dornfeld D, Götz V, Zell R, Zimmermann P, Haller O, Kochs G, Schwemmle M. 2013. Pandemic influenza A viruses escape from restriction by human MxA through adaptive mutations in the nucleoprotein. PLoS Pathog 9: e1003279. doi:10.1371/journal.ppat.1003279

Marazzi I, Ho JS, Kim J, Manicassamy B, Dewell S, Albrecht RA, Seibert CW, Schaefer U, Jeffrey KL, Prinjha RK, et al. 2012. Suppression of the antiviral response by an influenza histone mimic. Nature 483: 428-433. doi:10.1038/ nature 10892

Marcus PI, Rojek JM, Sekellick MJ. 2005. Interferon induction and/or production and its suppression by influenza A viruses. J Virol 79: 2880-2890. doi:10.1128/JVI.79.5 $.2880-2890.2005$

Melén K, Kinnunen L, Fagerlund R, Ikonen N, Twu KY, Krug RM, Julkunen I. 2007. Nuclear and nucleolar targeting of influenza A virus NS1 protein: striking differences between different virus subtypes. J Virol 81: 5995-6006. doi:10.1128/JVI.01714-06

Meurs E, Chong K, Galabru J, Thomas NS, Kerr IM, Williams BR, Hovanessian AG. 1990. Molecular cloning and characterization of the human double-stranded RNA-activated protein kinase induced by interferon. Cell 62: 379390. doi:10.1016/0092-8674(90)90374-N

Mibayashi M, Martínez-Sobrido L, Loo YM, Cárdenas WB, Gale M Jr, García-Sastre A. 2007. Inhibition of retinoic acid-inducible gene I-mediated induction of beta interferon by the NS1 protein of influenza A virus. J Virol 81: 514-524. doi:10.1128/JVI.01265-06

Min JY, Li S, Sen GC, Krug RM. 2007. A site on the influenza A virus NS1 protein mediates both inhibition of PKR activation and temporal regulation of viral RNA synthesis. Virology 363: 236-243. doi:10.1016/j.virol 2007.01.038

Morreale FE, Walden H. 2016. Types of ubiquitin ligases. Cell 165: 248-248.e11. doi:10.1016/j.cell.2016.03 .003

Muñoz-Moreno R, Martínez-Romero C, Blanco-Melo D, Forst CV, Nachbagauer R, Benitez AA, Mena I, Aslam S, Balasubramaniam V, Lee I, et al. 2019. Viral fitness landscapes in diverse host species reveal multiple evo- 
lutionary lines for the NS1 gene of influenza A viruses. Cell Rep 29: 3997-4009.e5. doi:10.1016/j.celrep.2019.11.070

Myong S, Cui S, Cornish PV, Kirchhofer A, Gack MU, Jung JU, Hopfner KP, Ha T. 2009. Cytosolic viral sensor RIG-I is a $5^{\prime}$-triphosphate-dependent translocase on doublestranded RNA. Science 323: 1070-1074. doi:10.1126/sci ence.1168352

Narasimhan J, Wang M, Fu Z, Klein JM, Haas AL, Kim JJ. 2005. Crystal structure of the interferon-induced ubiquitin-like protein ISG15. J Biol Chem 280: 27356-27365. doi:10.1074/jbc.M502814200

Nemeroff ME, Barabino SM, Li Y, Keller W, Krug RM. 1998. Influenza virus NS1 protein interacts with the cellular 30 $\mathrm{kDa}$ subunit of CPSF and inhibits $3^{\prime}$ end formation of cellular pre-mRNAs. Mol Cell 1: 991-1000. doi:10.1016/ S1097-2765(00)80099-4

Noah DL, Twu KY, Krug RM. 2003. Cellular antiviral responses against influenza $\mathrm{A}$ virus are countered at the posttranscriptional level by the viral NS1A protein via its binding to a cellular protein required for the $3^{\prime}$ end processing of cellular pre-mRNAS. Virology 307: $386-$ 395. doi:10.1016/S0042-6822(02)00127-7

Obenauer JC, Denson J, Mehta PK, Su X, Mukatira S, Finkelstein DB, Xu X, Wang J, Ma J, Fan Y, et al. 2006. Largescale sequence analysis of avian influenza isolates. Science 311: 1576-1580. doi:10.1126/science.1121586

O’Neill LA, Bowie AG. 2011. The powerstroke and camshaft of the RIG-I antiviral RNA detection machine. Cell 147: 259-261. doi:10.1016/j.cell.2011.09.027

Oshiumi H, Miyashita M, Inoue N, Okabe M, Matsumoto M, Seya T. 2010. The ubiquitin ligase Riplet is essential for RIG-I-dependent innate immune responses to RNA virus infection. Cell Host Microbe 8: 496-509. doi:10.1016/j .chom.2010.11.008

Oudshoorn D, van Boheemen S, Sánchez-Aparicio MT, Rajsbaum R, García-Sastre A, Versteeg GA. 2012 HERC6 is the main E3 ligase for global ISG15 conjugation in mouse cells. PLoS One 7: e29870. doi:10.1371/journal .pone.0029870

Ouyang J, Zhu X, Chen Y, Wei H, Chen Q, Chi X, Qi B, Zhang L, Zhao Y, Gao GF, et al. 2014. NRAV, a long noncoding RNA, modulates antiviral responses through suppression of interferon-stimulated gene transcription. Cell Host Microbe 16: 616-626. doi:10.1016/j.chom.2014 .10 .001

Pang IK, Iwasaki A. 2012. Control of antiviral immunity by pattern recognition and the microbiome. Immunol Rev 245: 209-226. doi:10.1111/j.1600-065X.2011.01073.x

Patil G, Zhao M, Song K, Hao W, Bouchereau D, Wang L, Li S. 2018. TRIM41-mediated ubiquitination of nucleoprotein limits influenza A virus infection. J Virol 92. doi:10 $.1128 /$ JVI.00905-18

Perreira JM, Chin CR, Feeley EM, Brass AL. 2013. IFITMs restrict the replication of multiple pathogenic viruses. J Mol Biol 425: 4937-4955. doi:10.1016/j.jmb.2013.09 .024

Pichlmair A, Schulz O, Tan CP, Naslund TI, Liljestrom P, Weber F, Reis e Sousa C. 2006. RIG-I-mediated antiviral responses to single-stranded RNA bearing 5 '-phosphates. Science 314: 997-1001. doi:10.1126/science.1132998
Pinto LH, Holsinger LJ, Lamb RA. 1992. Influenza virus M2 protein has ion channel activity. Cell 69: 517-528. doi:10 $.1016 / 0092-8674(92) 90452-I$

Platanias LC. 2005. Mechanisms of type-I- and type-II-interferon-mediated signalling. Nat Rev Immunol 5: 375386. doi:10.1038/nril604

Rajsbaum R, Albrecht RA, Wang MK, Maharaj NP, Versteeg GA, Nistal-Villan E, García-Sastre A, Gack MU. 2012. Species-specific inhibition of RIG-I ubiquitination and IFN induction by the influenza A virus NS1 protein. PLoS Pathog 8: e1003059. doi:10.1371/journal.ppat .1003059

Rehwinkel J, Tan CP, Goubau D, Schulz O, Pichlmair A, Bier K, Robb N, Vreede F, Barclay W, Fodor E, et al. 2010. RIGI detects viral genomic RNA during negative-strand RNA virus infection. Cell 140: 397-408. doi:10.1016/j.cell.2010 .01 .020

Robertsen B. 2006. The interferon system of teleost fish. Fish Shellfish Immunol 20: 172-191. doi:10.1016/j.fsi.2005.01 .010

Rossman JS, Lamb RA. 2009. Autophagy, apoptosis, and the influenza virus M2 protein. Cell Host Microbe 6: 299-300. doi:10.1016/j.chom.2009.09.009

Sakaguchi T, Leser GP, Lamb RA. 1996. The ion channel activity of the influenza virus M2 protein affects transport through the Golgi apparatus. J Cell Biol 133: 733-747. doi:10.1083/jcb.133.4.733

Schneider WM, Chevillotte MD, Rice CM. 2014. Interferonstimulated genes: a complex web of host defenses. Annu Rev Immunol 32: 513-545. doi:10.1146/annurev-immu nol-032713-120231

Shapira SD, Gat-Viks I, Shum BO, Dricot A, de Grace MM, Wu L, Gupta PB, Hao T, Silver SJ, Root DE, et al. 2009. A physical and regulatory map of host-influenza interactions reveals pathways in $\mathrm{H} 1 \mathrm{~N} 1$ infection. Cell 139: 1255-1267. doi:10.1016/j.cell.2009.12 .018

Shaw M, Palese P. 2013. Orthomyxoviridae. In: Fiels Virology, 6th ed. (ed. Knipe DM, Howley P), pp. 1151-1185. Lippincott Williams \& Wilkins, Philadelphia, PA.

Shin N, Pyo CW, Jung KI, Choi SY. 2015. Influenza A virus $\mathrm{PB} 1-\mathrm{F} 2$ is involved in regulation of cellular redox state in alveolar epithelial cells. Biochem Biophys Res Commun 459: 699-705. doi:10.1016/j.bbrc .2015 .03 .010

Shinya K, Ebina M, Yamada S, Ono M, Kasai N, Kawaoka Y. 2006. Avian flu: influenza virus receptors in the human airway. Nature 440: 435-436. doi:10.1038/440435a

Soubies SM, Volmer C, Croville G, Loupias J, Peralta B, Costes P, Lacroux C, Guérin JL, Volmer R. 2010. Species-specific contribution of the four C-terminal amino acids of influenza A virus NS1 protein to virulence. J Virol 84: 6733-6747. doi:10.1128/JVI.02427-09

Sridharan H, Zhao C, Krug RM. 2010. Species specificity of the NS1 protein of influenza B virus: NS1 binds only human and non-human primate ubiquitin-like ISG15 proteins. J Biol Chem 285: 7852-7856. doi:10.1074/jbc .C109.095703

Staeheli P, Haller O, Boll W, Lindenmann J, Weissmann C. 1986. Mx protein: constitutive expression in 3T3 cells transformed with cloned Mx cDNA confers selective re- 
R. Muñoz-Moreno et al.

sistance to influenza virus. Cell 44: 147-158. doi:10.1016/ 0092-8674(86)90493-9

Staeheli P, Grob R, Meier E, Sutcliffe JG, Haller O. 1988. Influenza virus-susceptible mice carry $M x$ genes with a large deletion or a nonsense mutation. Mol Cell Biol 8: 4518-4523. doi:10.1128/MCB.8.10.4518

Su Q, Wang S, Baltzis D, Qu LK, Wong AH, Koromilas AE. 2006. Tyrosine phosphorylation acts as a molecular switch to full-scale activation of the eIF $2 \alpha$ RNA-dependent protein kinase. Proc Natl Acad Sci 103: 63-68. doi:10 .1073/pnas.0508207103

Sun X, Sun L, Zhao Y, Li Y, Lin W, Chen D, Sun Q. 2016. MAVS maintains mitochondrial homeostasis via autophagy. Cell Discov 2: 16024 . doi:10.1038/celldisc .2016 .24

Takahasi K, Kumeta H, Tsuduki N, Narita R, Shigemoto T, Hirai R, Yoneyama M, Horiuchi M, Ogura K, Fujita T, et al. 2009. Solution structures of cytosolic RNA sensor MDA5 and LGP2 C-terminal domains: identification of the RNA recognition loop in RIG-I-like receptors. J Biol Chem 284: 17465-17474. doi:10.1074/jbc .M109.007179

Takeshita F, Tanaka T, Matsuda T, Tozuka M, Kobiyama K, Saha S, Matsui K, Ishii KJ, Coban C, Akira S, et al. 2006. Toll-like receptor adaptor molecules enhance DNAraised adaptive immune responses against influenza and tumors through activation of innate immunity. J Virol $\mathbf{8 0}$ : 6218-6224. doi:10.1128/JVI.00121-06

Taubenberger JK, Kash JC, Morens DM. 2019. The 1918 influenza pandemic: 100 years of questions answered and unanswered. Sci Transl Med 11. doi:10.1126/sci translmed.aau5485

Thomis DC, Samuel CE. 1992. Mechanism of interferon action: autoregulation of RNA-dependent P1/eIF- $2 \alpha$ protein kinase (PKR) expression in transfected mammalian cells. Proc Natl Acad Sci 89: 10837-10841. doi:10.1073/ pnas.89.22.10837

Twu KY, Noah DL, Rao P, Kuo RL, Krug RM. 2006. The CPSF30 binding site on the NS1A protein of influenza A virus is a potential antiviral target. J Virol 80: 3957-3965. doi:10.1128/JVI.80.8.3957-3965.2006

van Riel D, den Bakker MA, Leijten LM, Chutinimitkul S, Munster VJ, de Wit E, Rimmelzwaan GF, Fouchier RA, Osterhaus AD, Kuiken T. 2010. Seasonal and pandemic human influenza viruses attach better to human upper respiratory tract epithelium than avian influenza viruses. Am J Pathol 176: 1614-1618. doi:10.2353/ajpath.2010 .090949

Varga ZT, Ramos I, Hai R, Schmolke M, García-Sastre A, Fernandez-Sesma A, Palese P. 2011. The influenza virus protein PB1-F2 inhibits the induction of type I interferon at the level of the MAVS adaptor protein. PLoS Pathog 7: e1002067. doi:10.1371/journal.ppat.1002067

Venkataraman T, Valdes M, Elsby R, Kakuta S, Caceres G, Saijo S, Iwakura Y, Barber GN. 2007. Loss of DExD/H box RNA helicase LGP2 manifests disparate antiviral responses. J Immunol 178: 6444-6455. doi:10.4049/jimmunol .178 .10 .6444

Verhelst J, Parthoens E, Schepens B, Fiers W, Saelens X. 2012. Interferon-inducible protein $\mathrm{Mx} 1$ inhibits influenza virus by interfering with functional viral ribonucleopro- tein complex assembly. J Virol 86: 13445-13455. doi:10 .1128/JVI.01682-12

Vidy A, Maisonnasse P, Da Costa B, Delmas B, Chevalier C, Le Goffic R. 2016. The influenza virus protein PB1-F2 increases viral pathogenesis through neutrophil recruitment and NK cells inhibition. PLoS One 11: e0165361. doi:10.1371/journal.pone.0165361

Wagaman PC, Spence HA, O'Callaghan RJ. 1989. Detection of influenza $\mathrm{C}$ virus by using an in situ esterase assay. $J$ Clin Microbiol 27: 832-836. doi:10.1128/JCM.27.5.832836.1989

Wang B, Lam TH, Soh MK, Ye Z, Chen J, Ren EC. 2018. Influenza A virus facilitates its infectivity by activating p53 to inhibit the expression of interferon-induced transmembrane proteins. Front Immunol 9: 1193. doi:10.3389/ fimmu.2018.01193

Wang P, Zheng M, Lau SY, Chen P, Mok BW, Liu S, Liu H, Huang X, Cremin CJ, Song W, et al. 2019a. Generation of DelNS1 influenza viruses: a strategy for optimizing live attenuated influenza vaccines. MBio 10: e02180-19.

Wang R, Zhu Y, Lin X, Ren C, Zhao J, Wang F, Gao X, Xiao R, Zhao L, Chen H, et al. 2019b. Influenza M2 protein regulates MAVS-mediated signaling pathway through interacting with MAVS and increasing ROS production. Autophagy 15: 1163-1181. doi:10.1080/15548627.2019 .1580089

WHO. 2018. Seasonal Influenza Fact Sheet.

Wu X, Wang J, Wang S, Wu F, Chen Z, Li C, Cheng G, Qin FX. 2019. Inhibition of influenza A virus replication by TRIM14 via its multifaceted protein-protein interaction with NP. Front Microbiol 10: 344. doi:10.3389/fmicb.2019 .00344

Yi C, Zhao Z, Wang S, Sun X, Zhang D, Sun X, Zhang A, Jin M. 2017. Influenza A virus PA antagonizes interferon- $\beta$ by interacting with interferon regulatory factor 3. Front Immunol 8: 1051. doi:10.3389/fimmu .2017 .01051

Yuan W, Krug RM. 2001. Influenza B virus NS1 protein inhibits conjugation of the interferon (IFN)-induced ubiquitin-like ISG15 protein. EMBO J 20: 362-371. doi:10.1093/emboj/20.3.362

Zhang R, Chi X, Wang S, Qi B, Yu X, Chen JL. 2014. The regulation of autophagy by influenza A virus. Biomed Res Int 2014: 498083.

Zhang X, Bogunovic D, Payelle-Brogard B, Francois-Newton V, Speer SD, Yuan C, Volpi S, Li Z, Sanal O, Mansouri D, et al. 2015. Human intracellular ISG15 prevents interferon- $\alpha / \beta$ over-amplification and auto-inflammation. $\mathrm{Na}$ ture 517: 89-93. doi:10.1038/nature13801

Zhang K, Xie Y, Muñoz-Moreno R, Wang J, Zhang L, Esparza M, García-Sastre A, Fontoura BMA, Ren Y. 2019. Structural basis for influenza virus NS1 protein block of mRNA nuclear export. Nature Microbiology 4: 16711679. doi:10.1038/s41564-019-0482-x

Zhao C, Beaudenon SL, Kelley ML, Waddell MB, Yuan W, Schulman BA, Huibregtse JM, Krug RM. 2004. The UbcH8 ubiquitin E2 enzyme is also the E2 enzyme for ISG15, an IFN- $\alpha / \beta$-induced ubiquitin-like protein. Proc Natl Acad Sci 101: 7578-7582. doi:10.1073/pnas .0402528101 
Interferon Responses during Influenza A Virus Infections

Zhao C, Hsiang TY, Kuo RL, Krug RM. 2010. ISG15 conjugation system targets the viral NS1 protein in influenza A virus-infected cells. Proc Natl Acad Sci 107: 2253-2258. doi:10.1073/pnas.0909144107

Zhao Y, Sun X, Nie X, Sun L, Tang TS, Chen D, Sun Q. 2012. COX5B regulates MAVS-mediated antiviral signaling through interaction with ATG5 and repressing ROS production. PLoS Pathog 8: e1003086. doi:10.1371/journal .ppat.1003086

Zhao X, Li J, Winkler CA, An P, Guo JT. 2019. IFITM genes, variants, and their roles in the control and pathogenesis of viral infections. Front Microbiol 9: 3228. doi:10.3389/ fmicb.2018.03228
Zhu J, Zhang Y, Ghosh A, Cuevas RA, Forero A, Dhar J, Ibsen MS, Schmid-Burgk JL, Schmidt T, Ganapathiraju MK, et al. 2014. Antiviral activity of human OASL protein is mediated by enhancing signaling of the RIG-I RNA sensor. Immunity 40: 936-948. doi:10.1016/j.immuni .2014 .05 .007

Zhu J, Ghosh A, Sarkar SN. 2015. OASL-a new player in controlling antiviral innate immunity. Curr Opin Virol 12: 15-19. doi:10.1016/j.coviro.2015.01.010

Zimmermann P, Manz B, Haller O, Schwemmle M, Kochs G. 2011. The viral nucleoprotein determines Mx sensitivity of influenza A viruses. J Virol 85: 8133-8140. doi:10 $.1128 /$ JVI.00712-11 


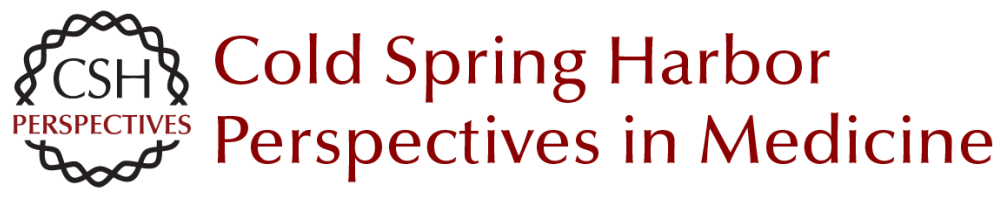

\title{
Induction and Evasion of Type-I Interferon Responses during Influenza A Virus Infection
}

\author{
Raquel Muñoz-Moreno, Carles Martínez-Romero and Adolfo García-Sastre
}

Cold Spring Harb Perspect Med published online July 6, 2020

\section{Subject Collection Influenza: The Cutting Edge}

$\begin{array}{lc}\text { Emerging HxNy Influenza A Viruses } & \text { Antivirals Targeting the Neuraminidase } \\ \text { William J. Liu, Yan Wu, Yuhai Bi, et al. } & \text { Larisa Gubareva and Teena Mohan } \\ \text { Equine Influenza } & \text { Accessory Gene Products of Influenza A Virus } \\ \text { Thomas M. Chambers } & \text { Rute M. Pinto, Samantha Lycett, Eleanor Gaunt, et } \\ & \text { al. } \\ \text { Human Influenza Epidemiology } & \text { Influenza Immunization in the Context of } \\ \text { Sukhyun Ryu and Benjamin J. Cowling } & \text { Preexisting Immunity } \\ & \text { Susanne L. Linderman, Ali H. Ellebedy, Carl Davis, } \\ & \text { et al. } \\ \text { Host Cell Factors That Interact with Influenza } & \text { Hemagglutinin Structure and Activities } \\ \text { Virus Ribonucleoproteins } & \text { Steven J. Gamblin, Sébastien G. Vachieri, Xiaoli } \\ \text { Ecco Staller and Wendy S. Barclay } & \text { Xiong, et al. } \\ \text { Induction and Evasion of Type-I Interferon } & \text { Live Attenuated Cold-Adapted Influenza Vaccines } \\ \text { Responses during Influenza A Virus Infection } & \text { Kanta Subbarao } \\ \text { Raquel Muñoz-Moreno, Carles Martinez-Romero } & \\ \text { and Adolfo García-Sastre } & \\ \text { Structure and Function of Influenza Polymerase } & \text { Next-Generation Influenza Vaccines } \\ \text { Joanna M. Wandzik, Tomas Kouba and Stephen } & \text { Masaru Kanekiyo and Barney S. Graham } \\ \text { Cusack } & \\ \text { H7N9 Influenza Virus in China } & \text { Selective Genome Packaging Mechanisms of } \\ \text { Chengjun Li and Hualan Chen } & \text { Takeshi Noda } \\ \text { Influenza A Viruses } & \text { Tystems Biological Analysis of Immune Response } \\ \text { H5 Influenza Viruses in Egypt } & \text { To Influenza Vaccination } \\ \text { Rabeh El-Shesheny, Ahmed Kandeil, Ahmed } & \text { Mario Cortese, Amy C. Sherman, Nadine G. } \\ \text { Mostafa, et al. } & \text { Rouphael, et al. }\end{array}$

For additional articles in this collection, see http://perspectivesinmedicine.cshlp.org/cgi/collection/ 